\title{
Makeover accounting: Investigating the meaning-making practices of financial accounts
}

\author{
Charlotta Bay \\ Stockholm Business School, Stockholm University, SE-106 91 Stockholm, Sweden
}

\section{A R T I C L E I N F O}

\section{Keywords:}

Accounting effect

Interpretation

Re-presentation

Signifying practices

Financial edutainment

Everyday life

\begin{abstract}
A B S T R A C T
The constitutive ability of accounting to produce effects, influencing people's minds and behaviour, has been widely acknowledged in accounting literature. This paper argues, however, that in order for accounting to have an impact on people, its figures needs to be interpretable to its intended users. But what happens in situations where people are considered as inhibited in reading and interpreting financial information? This paper investigates how financial accounts are presented to individuals believed to be impaired in their ability to make sense of its figures. It does so by moving the empirical focus beyond the borders of the professional organisation and into the private sphere of everyday life, examining how a televised financial makeover show literally represents financial information in order to turn its participants into financially responsible citizens. The paper's empirical findings give reasons for problematising the conditions under which accounting is able to affect people, concluding that, without taking people's ability to interpret financial accounts into consideration, the possibilities of the accounts having an impact on their users risk falling short.
\end{abstract}

\section{Introduction}

The issue of how to influence people to become responsible employees, managers, and CEOs has been largely elaborated within the accounting research area. Processes of accountability have long been recognised as difficult, contradictory and highly complex (Messner, 2009; Qu \& Cooper, 2011; Roberts, 1991), embodying chameleon like qualities (Sinclair, 1995). Regardless of its multiplicity of manifestations, accounting is nevertheless widely acknowledged as a critical means for those processes to produce financially knowledgeable people (e.g. Ahrens, 1996; Roberts \& Scapens, 1985), transforming them to think and act in rational and responsible ways (Miller \& O'Leary, 1990). The possibility, however, of affecting people by means of accounting devices is said to presuppose a certain accounting literacy (Bay, Catasús, \& Johed, 2014), an ability that enables individuals to read and make use of accounting information (Carruthers \& Espeland, 1991; Kirk \& Mouritsen, 1996). This relation between people's ability to interpret accounting representations and the expected effects thereof has received only minor attention in accounting research, possibly due to the fact that most studies are concerned with people's professional practices, where accounting information is presumed to make sense to its users.

However well established in work spaces, people's familiarity with accounting information is arguably less developed outside the sphere of the professional organisation, in the world of the individual's daily way of life. Perhaps in contrast to the organisational arena, this is an area partly consisting of individuals struggling to keep up with and adjusting to a modern way of running one's private financial affairs. Even so, the financial stories that we are fed by the news and neighbours, brokers and banks, spelling out the demands by which we are expected to live, are still stuffed with references to numbers, tables, calculations and indicators. This arguably constitutes a dilemma, because, as Qu and Cooper (2011) point out, in order for this quantitative information to be useful, it needs to be made interpretable to its intended recipient. Addressing this quandary, this paper aims to examine how financial information is presented to people whose interpretive ability to make sense of its forms and accounts is considered limited or impaired.

The media is claimed as an arena where complex financial issues get translated into intelligible stories of everyday life (e.g. Frank, 2001; Grafström, 2005; Martin, 2002). Rehn and Sköld (2010), for instance, discern a democratising trend in how the contemporary media reports on finance matters. They argue that the evening press "sees as one of its tasks to make the economy a less intimidating and more accessible phenomenon" (p. 130). And Johed (2007) demonstrates, for example, that business journalists act as a kind of accounting brokers, translating formal accounting reports into comprehensible investment arguments in order to broaden the shareholder culture into the public realm. This paper follows in the footsteps of these media, addressing an everyday activity most commonly conducted from the living-room sofa watching TV. Here, the empirical point of investigation constitutes a

E-mail address: charlotta.bay@sbs.su.se. 
Swedish television show, the Luxury Trap (Lyxfällan). This is a financial makeover programme starring two financial advisors on a mission "to get ordinary Swedish households out of the red" (FridayTV, 2009), transforming "middle-class shopaholics" (ibid) into financially responsible subjects. The paper demonstrates how accounting, as technique(s) as well as rationale, is drawn on in televised financial entertainment, examining how the Luxury Trap represents or, perhaps more precisely, re-presents numbers and financial accounts in order to influence the participants' way of making sense of their financial situation.

Theoretically, this paper problematises the circumstances under which accounting is said to function as a constitutive device in rendering people financially responsible. This does not mean that the paper discards the idea of accounting as a producer of effects. Rather, its aim is to examine those conditions that are believed to enable those effects to occur. The paper argues that in order for an accounting representation to make an impact, its intended audience needs to be able to make sense of it. This means that financial accounts must be presented so as to become meaningful to its recipients. Informed by Hall's theory of communication (Hall, 1980, 1997a-d), this paper extends and refines literature that examines how accounting is constructed in order to be convincing (e.g. Abrahamsson, Englund, \& Gerdin, 2016; Ahrens, 1997; Catasús, Ersson, Gröjer, \& Wallentin, 2007; Qu \& Cooper, 2011; Robson, 1992; Vollmer, 2007) by highlighting the implication of the user's ability to interpret of financial information. In this way, the paper opens up a space where assumptions about accounting's constitutive power might be discussed and problematised.

Empirically, this paper is premised on the idea that accounting is a situated practice, constructed at all levels of social life, and that its analysis should not be restricted to the traditional level of the professional organisation. By entering people's living rooms, turning on their TVs, this paper challenges previous accounting research by moving "beyond the confines of business hours" (Jeacle, 2010, p. 2), leaving "organisations as the exclusive level of research" (Miller, 1994, p. 1). As indicated by Jeacle (2012), such a study contributes to a broadening of the empirical scope of accounting research to also explore its role in media and popular culture.

The paper starts off by taking a small detour, elaborating on the significance of taking recipient interpretation into consideration in making financial accounts effect-ful. Thereafter, the theoretical resources are presented, delineating the key arguments of Stuart Hall's theory of communication. In the subsequent section, the empirical setting is introduced, positioning the object of investigation in a contemporary context of the television genre of which it forms part. Prior to the analysis part, the design of the study is outlined. The paper concludes with a discussion of its empirical findings and theoretical contributions.

\section{The role of interpretations}

The "constitutive turn", as Asdal (2011, p. 1) calls it, has been widely influential for the past few decades in the social accounting research area. Its adherents argue that by virtue of accounting's ability to make certain aspects of social and economic activity visible, its representations help to frame a specific understanding of reality, which in turn makes people act in accordance with it (Ezzamel, Lilley, \& Willmott, 2004; Miller, 1994; Napier, 2006). As such, accounting might be said to serve rhetorical purposes (Aho, 2005; Arrington \& Francis, 1993; Thompson, 1994; Young, 2003), not merely used to inform but also to influence, persuade and manipulate people to look upon their world and themselves in particular ways (Carruthers \& Espeland, 1991). Hence, from the constitutive point of view, accounting is not only a technical practice used to report on economic activities, but also a social and political one (Hopwood, 1987), employed to intervene and transform human economic behaviour in public and organisational life.

However well-established this thinking may be, there are examples to be found in the accounting literature that take a more problematising approach towards this alleged constitutive capacity of accounting representations (e.g. Abrahamsson et al., 2016; Ahrens, 1997; Bay et al., 2014; Boland, 1993; Vollmer, 2003, 2007). Oakes, Townley, and Cooper (1998), for example, argue that even though accounting is recognised as an effective means in bringing about change, this effect should not be taken for granted, concluding that "the process through which this occurs is more complex than much of the current literature suggests" (p. 258). Catasús et al. (2007) assert in the same vein that even though financial accounts of all kinds - measurements, figures, numbers, indicators, statistics - are likely to inform and encourage people to act in a specific manner, they do not per se guarantee such action. Instead it is suggested that the effects of accounts are dependent on how they are interpreted by their users (Ezzamel et al., 2004) and, to draw on Munro (1993), such an interpretation is not determined by the accounts per se. This implies that the interpretation of numbers, for example, is not of an uncontroversial kind. Rather, it suggests that due to their lack of intrinsic meaning (Catasús, 2010), numbers can mean different things to different audiences (Qu \& Cooper, 2011; see also Quattrone, 2009), creating potential uncertainties of how they are to be interpreted and acted upon by their intended users (Abrahamsson et al., 2016).

These remarks are worth considering when taking a closer look at the financial status of contemporary citizens. Concurrently with an increasing financialisation of people's daily life (Martin, 2002), where citizens are expected to independently navigate through difficult pension systems and cope with high-risk saving investments (e.g. Erturk, Froud, Johal, Leaver, \& Williams, 2007; Finlayson, 2009; Langley, 2008; Williams, 2007), the demands on their ability to read and act on financial information have sharpened (Greenfield \& Williams, 2007; Harmes, 2001; Langley, 2007). However, far from all citizens live up to fulfill these demands. Higher levels of over-indebtedness ${ }^{1}$ and personal bankruptcies signal that people have difficulties managing their own finances, manifested in, for example, unsuccessful investment strategies, increasing house mortgages, and over-consumption (OECD., 2005). These findings not only raise concerns about how well equipped people are to make financial decisions. They also indicate that there seems to be discrepancies between the way that produced financial information is expected to be understood and the way in which that information is interpreted and acted on by its recipients. In a series of reports, commissioned by the Swedish Financial Supervisory Authority (FSA), Almenberg and Widmark (2011) note that "many adults struggle with basic calculations and lack an understanding of elementary financial concepts" (p. 2). The authors conclude that since quantitative information can be perceived differently by different consumers, it is not very effective to provide financial information in ways that consumers are not adequately equipped to absorb. This, in turn, creates a quandary of communication, specifically that of how financial information should be communicated in order to make sense to its users.

The line of argument above suggests that unless made interpretable to users, the likelihood that financial information affects people's way of thinking and acting is curtailed. Hence, to acknowledge and act upon numbers, budgets, indicators, and other kinds of financial accounts as useful decision-making input requires a person endowed with an ability to extract the meaning of its figures and terminology. This is arguably not given by Nature and only made to occur if people are taught how to read, decode and interpret the accounts accordingly. Moreover, if and how financial accounts are acted upon is suggested to depend on how they are communicated and pedagogically presented in the local context in which they appear (Abrahamsson et al., 2016; Asdal, 2011; Catasús, 2010; Mouritsen, 2004; Qu \& Cooper, 2011). How to address this dilemma of communicating financial information so as to make it

\footnotetext{
${ }^{1}$ Used to describe a situation when debt or debt service payments relative to income become a major burden for the borrower (OECD., 2005, p. 63).
} 
interpretable to its intended audience is the inquiry of this paper.

In the case presented in this paper, we are about to meet people with a seemingly limited ability to engage with their strained personal finances. This inability should not primarily be understood as resulting from people being disabled, incapacitated or mentally unfit to manage their domestic financial affairs. Rather, their ability to do so is inhibited due to a variation of other reasons such as ignorance, indifference, inexperience or lack of competence, motivation, or denial. In the financial makeover programme the Luxury Trap, these people are assisted by two financial advisors whose task is to instruct the participants into developing a certain relation their own finances. This involves, more specifically, a detailed analysis of the activities whereby the participants' interpretation of financial accounts is addressed and worked on.

\section{Making numbers mean}

In studying how financial information is rendered in the makeover programme the Luxury Trap, this paper's analysis is informed by the cultural theorist Stuart Hall's communication theory. Inspired by Saussure's semiotic tradition and Foucault's discursive understanding of representation, Hall developed a theoretical approach to how media messages get produced and interpreted (1997a), also referred to as the encoding/decoding model of communication (1980). Applying Hall entails taking a constructionist view on financial information. This means that just like any other kind of representation - words, sounds, images, gestures, mimic, clothes - numbers and other financial accounts are here looked upon as signs or symbolic media, carrying meaning through which individuals make sense of the world and communicate with others.

Signs stand for or represent our concepts, ideas and feelings in such a way as to enable others to 'read', decode and interpret their meaning in roughly the same way that we do (Hall, 1997b, p.5).

According to Hall (1997b), it is however rare that representations in themselves possess any "one, single, fixed and unchanging meaning" (p. 3). This is what distinguishes the constructionist approach of communication from the reflective or mimetic ones (1997c). Hall argues that the mimetic approach understands meaning as being inherent in the material object or idea, and the representational sign functions like a mirror, reflecting and imitating the true meaning which is already presumed to be there. Further, the constructionist view also takes issue with the intentional approach. Here, exclusive precedence is given to the producer of a representation in determining its meaning according to his/her intentions. This is not to be understood as if constructionists deny the existence of a material world, or that people have intentions with their use of representations. Nevertheless, meaning to constructionists is not something absolute or something that just happens; it is neither to be found in the outside world nor inherent in the representation itself. Rather, the meaning of a representation is thought to be produced and constructed, and varies depending on what framework of interpretation is brought to it by the participating individuals. Hall argues that for making sense of a number, word or image in communicative practices, the meaning of the representation is as much dependent on the recipient's interpretation as it is of the producer's.

Hall's constructionist approach challenges the conventional view of how messages are said to be transferred from a sender to a recipient, criticising traditional models for their linearity (e.g. Shannon, 1948). Hall (1997c) argues that the meaning process of a representation is a highly situated issue and varies depending on the situation in which it occurs. This means that a representation can only be analysed in relation to who makes use of it and for what purpose in the actual concrete time and setting of which it forms a part. Moreover, Hall claims that traditional communication models tend to disempower the role of the audience. He proposes that the understanding of a message is not simply passively accepted by the audience, but that the recipient plays an active role in decoding or interpreting the message by means of his/ her own abilities and life experiences. A specific clothing outfit in one culture might therefore mean something else in another; a sum stated in numbers might be considered as wealth to the poor and poverty to the wealthy; and a chair might to the adult indicate something to sit on but is potentially a car or a rocket machine to the child. Hall (1997c) explains:

The meaning we take, as viewers, readers or audiences, is never exactly the meaning which has been given by the speaker or writer or by other viewers. (...) So the interpretation becomes an essential aspect of the process by which meaning is given and taken. The reader is as important as the writer in the production of meaning (p. 33).

Applied to the Luxury Trap, the numbers representing the families' debts do not initially provoke the same reaction among the participating families as they do to the families' financial advisors. This indicates that the families understand the numbers in a completely different way from what the producer of the numbers intended to convey. This entails implications, not only for the families but also for the way that the advisors re-present the numbers. Since effective communication is accomplished only when the numbers is interpreted in the intended way, it is essential that the advisors adjust the communication of the numbers so as to fit the families' interpretation scheme. Because, as Hall (1980) would have argued, a number that has not been intelligibly received is not, in effect, communicatively meaningful.

The accounts above entail that a producer of financial information cannot presume or take for granted that the meaning that $\mathrm{s} /$ he puts into it is the same as the one that its recipient takes out. Consequently, the information has to be worked on, provided with a convincing translation that facilitates the recipient's way of interpreting it in accordance with the producer's view. These translation activities are referred to as "signifying practices" (Hall, 1997d), i.e. meaning-producing activities that imbue numbers and other financial accounts with a certain interpretation.

The production of meaning means that there is a kind of symbolic work, an activity, a practice, which has to go on in giving meaning to things and in communicating that meaning to someone else (Hall, 1997d, p. 14).

Moreover, since the objective of signifying practices is to establish $a$ specific kind of interpretation, the practices need to be directed towards adjusting or altering earlier interpretations in accordance with the desired one. Such adjustment is thought to require a profound consideration and detailed knowledge of the recipient's characteristics, translating the financial information with respect to his/her specific context and conditions.

The signifying practices that are of concern to this paper are those activities and exercises used in the Luxury Trap to stand in for and translate financial numbers, making the participants to interpret their own finances in a certain (new) way. This involves analysing how the financial advisors literally re-present the participants' financial accounts in ways that enable the participants to establish a specific understanding of the financial information. Before turning to the analysis, the following section describes the empirical setting, positioning the Luxury Trap in a contemporary context of the television genre it partakes of.

\section{Makeover as edutainment}

To pitch an entertainment makeover programme as an enlightening medium for educating people about how to become financially capable may perhaps seem a bit far-fetched, or even naïve. Often, entertainment media are held to be a rather mindless genre with few ambitions other than to reach high ratings through pure amusement. However, such a perspective places entertaining in opposition to education, making 
them incompatible. This paper, on the other hand, takes the reverse stance. In line with Singhal and Rogers (1999), it argues that by combining the narrative entertainment format with instructive features, the makeover programme is taken beyond being a mere act of pleasure. Instead it is endowed with the potential to serve as an influential source from which people draw notions of how to think, act and behave in accordance with contemporary financial ideals.

The Luxury Trap forms part of an old but not yet completed transformation of Western leisure TV. For the past few decades, the televisual grammar has undergone several major changes that, according to previous research within the area of cultural studies (Brunsdon, 2004; Ouellette \& Hay, 2008; Taylor, 2002), need to be understood against a broader societal picture. It is argued that the recent wave of lifestyle and makeover shows, like the Luxury Trap, is a media manifestation of an on-going transition from civic to consumer society (Bauman, 1987). The latter is characterised by a culture inhabited by individuals incessantly occupied with refining their own lifestyle projects (Chaney, 2001). What to eat and wear, how to decorate and clean the house, or bring up kids, dogs and gardens - these concerns have all grown into matters of active individual lifestyle choices. Notably though, the consumerism that is intended in this case is not of the kind that glorifies the pleasures of impulsive shopping. On the contrary, what is proposed is a consumer awareness that seeks to stifle such impulsiveness, promoting wise and responsible habits performed by rational and autonomous subjects (Ouellette \& Hay, 2008).

The original makeover genre was one of beauty, style and external appearance. It remodels ordinary people into improved versions of themselves by equipping them with new clothes and new haircuts (e.g. What Not to Wear) or even new cheekbones (e.g. Extreme Makeover; The Swan). Eventually, the makeover extended its target areas to also include people's ways of leading their everyday lives, encompassing anything from parenting and neighbourship to health and housecleaning (e.g. Supernanny; Honey We're Killing the Kids; The Biggest Loser; Clean House). According to Andrews and Carter (2008), this refocusing marks a shift from the more shallow and stylistic transformations to the ones claiming to change the participants' lives in more profound ways. The following sections give an account of the arguments attributing the makeover with qualities that not only appeal to amusement but that encourage participants as well as viewers to learn from it.

Most lifestyle and makeover programmes cast 'ordinary' people, with 'ordinary' problems, in their 'ordinary' settings. By accentuating aspects of the humdrum and the mundane, this 'ordinari-isation' (Taylor, 2002) is argued to serve as a persuasive means of communication, as it invites viewers to relate to themselves. According to one of the financial advisors on the Luxury Trap, this is what makes even a subject as unspectacular as personal finances successful: "Everyone's got finances and everyone has financial troubles, more or less". Moreover, the makeover participants are people who appear as themselves rather than as fictional characters. They are used as sometimes extreme, demonstrative case studies, or as Redden (2007) puts it, "held up as exemplars of the ordinary and embodiments of an issue" (p. 151). As such, viewers are offered a figure against which they might measure themselves and their own progress. As the makeover casts 'ordinary' people and deals with an issue that concerns all of us, the Luxury Trap is claimed to support and serve as an inspiration not only to the show's participants but also to its viewers.

In this view, it is suggested that lifestyle and makeover programming functions as a coping mechanism or a moral compass, helping viewers to work through the ever changing expectations on how to lead a modern life (Bonner, 2003; Ouellette \& Hay, 2008; Redden, 2007; Taylor, 2002). By focusing attention on some aspects of life rather than others, these programmes inform and define what is important and help to establish a normalised view of 'ordinary' everyday life. Watching the judging of others in their capacities as parents, neighbours and petowners is assumed to provide guidelines for living that viewers are called upon to learn from and follow. Or as put in the Luxury Trap's information pamphlet: "We give advice that doesn't require a business degree to understand" (FridayTV, 2009). In this way, the lifestyle and makeover shows are claimed to hold "a measure of educational value for citizens" (Taylor, 2002, p. 491).

The Luxury Trap is a warm feel-good show that will inspire viewers and provide them with lots of helpful pointers (FridayTV, 2009).

Akin to commercial magazines, films and not least so-called selfhelp books, the makeover is here looked upon as a form of edutainment (Ouellette \& Hay, 2008) where instructive features operate in entertainment disguise to nurture citizenship and civil society, and serve as an instrument for educating, improving, and shaping subjects. Here, professionals are replaced by less formal so-called lifestyle experts equipped with a hybrid set of management techniques, problem-solving strategies, and therapeutic skills, helping middle-class people with their domestic lifestyle dilemmas. Hence, much of the makeover's attractive force is said to be attributed to its ability to address domestic micromoral domains of everyday life by weaving educational concerns into a largely entertainment-oriented script (Lewis, 2008). The Luxury Trap belongs to this genre of televised infotainment, characterised by consumer education twisted into social work intervention, teaching participants as well as viewers how to help themselves.

\section{Design of study}

The study rests on data collected from several information sources. The empirical material is partly gathered from watching a selection of twenty 45-min Luxury Trap episodes broadcasted in Sweden during the first nine seasons, from autumn 2006 to autumn 2010. The episodes were collected from the website of the broadcaster, Channel $3 .^{2}$ In the following, a list of the selected programmes is presented, referring to their broadcast season, episode, and date. (See Table 1).

Besides the archival data, six interviews have been carried out with three financial advisors and three producers/programme developers. The interview data was collected during a four-week period in November-December 2009. Below is a table listing the respondents and their respective function in the Luxury Trap production. (See Table 2).

The interviews varied between one and $2 \mathrm{~h}$ in length. They took place in the informants' offices, apart from one interview that was carried out at a restaurant. In order to give the interviews a less formal character, to make them more conversation-like, most of them were performed without the taking of written notes. Instead, the dialogues were recorded and then transcribed. The interviews were of a traditional semi-structured kind, involving a dozen open-ended questions for the interviewees to discuss and elaborate on. The informants were asked to give their subjective view and opinion on different topics related to the show such as the programme's idea and agenda, its content, design and format, and the potentially educational role it serves for its participants and audience. In addition, one promotion film and information pamphlets provided by the producers at Meter Film Production were studied.

As a methodological manual for giving structure to the collected data, a semiotic understanding of narrative analysis was employed (Greimas and Courtés, 1979/1982; Robichaud, 2003; Czarniawska, 1997, 2004). Narrative is in this sense understood as a methodological concept, referred to as a standardised structure (Brown, Yiannis, \& Gherardi, 2009), or a structural technique employed for interpreting text (e.g. books, films, theater, newspapers, annual reports). This means that the empirical investigation of the Luxury Trap was not only concerned with what was being said and done in the episodes, but rather with how it was said, i.e. the way the episodes were organised in order to guide the viewer's sense making of the general story. As a result, the coding of the Luxury Trap material principally aimed at identifying the

\footnotetext{
2 https://www.viafree.se/program/livsstil/lyxfallan/.
} 
Table 1

List of Luxury Trap episodes observed by the author.

\begin{tabular}{|c|c|c|}
\hline Season (S) & Episode (E) & Broadcast Date \\
\hline \multirow[t]{2}{*}{ Autumn 2006 (S1) } & E1 & November 2 \\
\hline & E5 & November 30 \\
\hline \multirow[t]{2}{*}{ Spring 2007 (S2) } & $\mathrm{E} 2$ & April 5 \\
\hline & E6 & May 3 \\
\hline \multirow[t]{2}{*}{ Autumn 2007 (S3) } & E4 & November 29 \\
\hline & E5 & December 6 \\
\hline \multirow[t]{2}{*}{ Spring 2008 (S4) } & $\mathrm{E} 2$ & April 17 \\
\hline & E3 & April 24 \\
\hline \multirow[t]{2}{*}{ Autumn 2008 (S5) } & E3 & October 2 \\
\hline & E6 & October 23 \\
\hline \multirow[t]{2}{*}{ Spring 2009 (S6) } & E7 & March 12 \\
\hline & E10 & April 3 \\
\hline \multirow[t]{3}{*}{ Autumn 2009 (S7) } & E1 & September 4 \\
\hline & E2 & September 11 \\
\hline & E8 & October 22 \\
\hline \multirow[t]{3}{*}{ Spring 2010 (S8) } & E3 & March 25 \\
\hline & E5 & April 8 \\
\hline & E9 & May 6 \\
\hline \multirow[t]{2}{*}{ Autumn 2010 (S9) } & E6 & November 18 \\
\hline & E9 & December 9 \\
\hline
\end{tabular}

Table 2

List of The Luxury Trap respondents.

\begin{tabular}{ll}
\hline Interview Respondents & Luxury Trap Function \\
\hline Financial advisor 1 & Co-hosted the programme seasons \\
& $1-4 ; 7-8$ \\
Financial advisor 2 & Co-hosted the programme seasons 5-6 \\
Financial advisor 3 & Co-hosted the programme seasons 5-6 \\
Programme developer, Meter Film & Initiated programme idea \\
Producer 1/Programme developer, & Initiated programme idea; produced \\
$\quad$ Meter Film & season 1 \\
Producer 2, Meter Film & Produced seasons 2; 7;8 \\
\hline
\end{tabular}

narrative rationality (Fisher, 1984), used to build the Luxury Trap's story.

Inspired by narrative analysis as a way looking for story patterns, an overview of the selected Luxury Trap episodes was initially done in order to determine the general storyline form. To investigate the form of the story (Czarniawska, 2000) means to study how the episodes are scripted. This involves asking: who are the characters?; what are their roles?; what is its message?; and perhaps most importantly, how are the story's acts organised in order to get its message through? Accordingly, the coding of the Luxury Trap episodes resulted in three consecutive sub-units, forming a chronological path of standardised phases through which financial accounts pass and become transformed in each episode. In the first and introductory phase, the participants' private finances take quantitative forms, most commonly represented as numerical figures on paper. In the second phase, the figures transform into representations that aim to quite literally reveal what is producing or hiding behind the numbers on papers. Such representations often take physical or emotional guises, however never numerical. In the third and last phase, the qualitative forms of financial accounts found in the second phase are re-translated into their original quantitative representations. This observed storyline was also compared and adjusted to the statements made by the programme initiators about the idea and design of the Luxury Trap.

In accordance with the theoretical approach of this paper, the data coding also involved identifying signifying practices (Hall, 1997d), i.e. those activities that were specifically employed to transform and translate numbers or similar calculative elements. The findings were 'cut out' and pasted into the storyline phases. Such coding enabled the analysis to discern patterns and identify similar characteristics among different signifying activities occurring in the same episode phase. Based on the three phases, the Luxury Trap story might be described as a

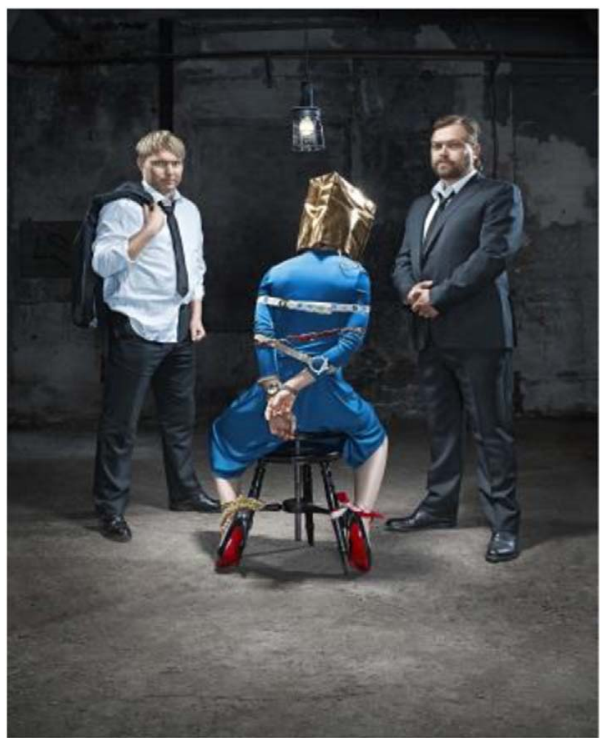

Fig. 1. The Luxury Trap, promo picture 2008. Photo: Channel 3 (TV3).

round-trip transformation journey that financial accounts take between numerical inscriptions on the one hand, and the 'reality' referents that these inscriptions are said to represent on the other. The storyline phases, concretised in further detail in the subsequent part of the paper, also form the structure of how the empirical findings are presented and analysed.

\section{The Luxury Trap case}

The Luxury Trap (see Fig. 1) is presented as a weekday "financial makeover" show (FridayTV, 2009). It is a Swedish product, produced by Meter Film Production, and was premiered by TV3 Sweden in 2006. According to Metronome Group, ${ }^{3}$ the Luxury Trap is the second highest rated show in the channel's history (after the programme Swedish Hollywood Wives), which during its peak was watched by ten per cent of the population (aged 12-59). The Luxury Trap also won the prize for the "Best Factual Series" at the Swedish TV Awards in both 2007 and 2008 (FridayTV, 2009). Apart from Sweden, where its 23rd season now is being broadcasted, the show is also running in other Scandinavian countries (Luksusfcelden, TV3 Denmark; Luksusfellen, TV3 Norway). Similar productions are also to be found elsewhere, such as Raus aus den Schulden (RTL, Germany) and Til Debt Do U\$ Part (Slice, Canada; Zone Reality, United Kingdom; CNBC, USA).

The participants in the Luxury Trap are described as non-fictional regular families, often with steady salaries, but who suffer from extraordinary spending issues, severe over-consumption and as a result, credit-card debts running riot (MeterFilm, 2009). The fact that the families' strained financial situation primarily results from over-consumption and not from a lack of income was an important requisite for participating in the programme, since lack of income is said to considerably restrict the supporting makeover measures. In the programme, two financial advisors are called in to help these people "who have ended up in dire financial straits" (MeterFilm, 2009) in order to eventually make them get back on track. The family is made to sign a contract in which it disclaims its own right to object to the decisions taken by the financial advisors about the household finances. Even though the Luxury Trap is an emotional roller coaster, it is also regarded as a feel-good show (FridayTV, 2009), always providing the viewers with a happy ending, a successful makeover and the contract torn up.

In the subsequent analysis, we are to follow how financial accounts

\footnotetext{
${ }^{3}$ Meter Film Production forms part of Metronome Group.
} 
in the Luxury Trap pass through different transformation phases in order to become interpretable to the participating families. The transformations are accomplished by means of exposing the participants to different kinds of exercises or, what Hall (1997d) would call, signifying practices. The aim of these exercises is ultimately to equip the participants with an understanding of their finances that is believed to eventually release them from their precarious financial situation.

\subsection{Introducing numbers}

Each episode of the Luxury Trap starts off by introducing a spectacle of shame. In its opening scene, the participants' financial and behavioural problems are outlined in order to make them (and the viewers) realise the gravity of the situation. Here, the participants are framed as naïve and irresponsible citizens, unable to lead a life that everybody else can. Their spending issues are portrayed as excessive, shameless and completely out of control, often rendered in quite striking ways. The following quotes represent statements made by family members when describing their financial habits (the codes in brackets refer to the broadcasting season (S) and episode (E) from which the quote is taken):

I haven't looked at my bills for the past eight years, 'cause I haven't regarded them as a part of my life (S8:E3).

My first breast operation was financed by a study loan. I know, it was unnecessary; it should have been used for something else (S8:E3).

The credit card is like my second income (S9:E6).

I usually put them [bills and demands] so as I can't see them. Because if I can't see them, they don't exist (S7:E1).

When the financial advisors arrive to the family, their first task is to try to create for themselves and the family a picture of how serious their financial position is. Initially, this is done by sitting down at the kitchen table with the family members, having a 'serious chat' in which the family is asked to give an account of their situation. These verbal accounts, a sort of accounting talk (Ahrens, 1997), are most often concerned with debts, credit loans, interests and mortgages, with references given to an unsorted pile of bills, reminders and debt demands lying in front of them. The message that is intended to be communicated is that the participants perceive their problems as somehow connected to the numerical figures on the papers but of which they can make no sense. The numbers are confusing to the participants and make their life a living hell. Financial advisor 2 comments:

Loans and debts ... That's what troubles them. If you solve these things, everything else will be resolved. But that's not the real problem. Well, they think so because most generally, their problems concern high interest rates and high repayments.

The advisor's comment implies that at this point of time, the family has not yet realised that even if their debt troubles, expressed in numbers on reminders and demand bills, were sorted out, their actual problem would still remain. He compares the resolving of debts and repayments to taking an aspirin: "it palliates the ache but does not cure the cause". It is thus argued that it is not primarily a lack of money but rather the participants' own choices in leading their lives that have put them in their strained financial situation. Because according to financial advisor 1, the financial status always reflects how one chooses to behave:

Finances are a result. They are the symptoms, but not the illness. Money is the result of something you do every day. And what you do will come out in your finances.

The point that the Luxury Trap initially wants to establish is that the participants have a deficient understanding of what the numerical accounts signify and stand for (Hall, 1980), and consequently need a

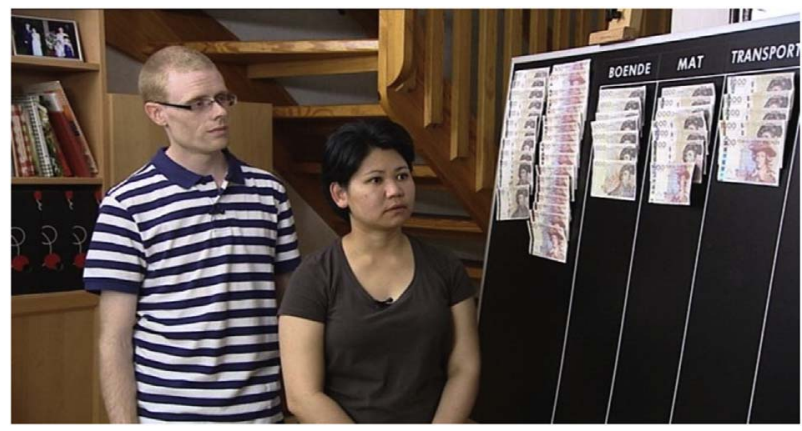

Fig. 2. The Luxury Trap's budget board. Photo: Channel 3 (TV3).

wake-up call. Since that has been proved not to be accomplished by expressing their financial situation by means of numerical signs, other perhaps more precise measures need to be taken.

\subsection{From numbers to 'reality'}

In the following parts, a selection of signifying practices (Hall, 1997d) is analysed. The practices demonstrate the activities aimed at giving (another) meaning to the numerical accounts on bills, receipts and debt demands. As the episode unfolds, these numbers are continuously translated into different kinds of non-numerical representations referring to the reality that the numbers are claimed to signify.

\subsubsection{The budget board}

The budget board constitutes a permanent segment in every episode, making up one of its famous pillars. It is introduced to visualise the expenditure priorities made by the family, pinpointing what the family spends their money on. Standing in front of this giant budget board ( $93 \times 175 \mathrm{~cm}$; see Fig. 2), the family is asked to estimate their monthly expenses according to pre-established columns of expenditure: 'housing', 'food', 'clothes', 'transportation', 'savings', 'loans', and 'other' (leisure). The advisors assist the family on site by adjusting and commenting on the sums according to expenditure research (e.g. statements of accounts) of which they have been informed in advance. As an attempt to reveal what hides behind the numbers, the comments disclose excessive details about the sums: how many pizzas they have eaten, how many hours they have talked on the cell phone, or how much more gas their car consumes than the average. Moreover, the total amounts are not put up in written figures. Instead, to reinforce the point that numbers must have the right properties in order to make sense (Catasús, 2010), they are re-presented by tangible paper currency notes, using money as a numeraire (Macintosh, Shearer, Thornton, \& Welker, 2000).

When counting the notes together, comparing the expenses to the family's actual income, the result seems to come across almost as a stroke of magic. Financial advisor 1 describes the effect of the budget board as a turning point for most family members, making them realise the severity of their financial situation:

The budget board - it's really crazy. Mathias and I [the advisors] have done it a hundred times. And every time, things start happening. Because then it becomes so obvious.

The budget board provides a lens that enables the family to quite literally see how they have chosen to lead their life. By quantifying their financial priorities in currency notes instead of in numbers, the budget board accords a specific type of visibility (Miller, 2001) that alters the way in which the participants' spending behaviour is thought about. One of the family members explains:

Just the fact that you got to see real money ... I don't think it would have helped much if it had been presented in numbers. That was when the coin dropped. (S1:E1) 
Other participants have similar experiences of revelations, describing the budget board exercise as "the moment of truth" (S3:E4), "a nightmare to see" (S5:E3), or "a wake-up call, a cold shower" (S7:E1). Hall (1997d) would argue that by changing the representation of their financial situation from numbers on receipts to currency notes on a budget board facilitates the families to interpret their finances differently. But why? Producer 2 suggests that the visualisation effect is key for provoking new insights:

The budget board is an example, clear as a bell, of how to visualise talk about money. To see real money on the budget board becomes more effective than to say "you spent 20,000 on this". In that way, words are not so much fun, but if you see real money in a column of course it will affect you more.

The visualisation that the budget board accords functions as a mirror where the self can be studied, reflected upon, surveyed and hence recalibrated (Roberts, 1991). This objectified and detached view of oneself helps the advisors to generate a point of intervention where potentially new questions can be asked, and new courses of action can be devised. This corresponds to Espeland and Stevens' (2008) declaration that "measurements are reactive: they cause people to think and act differently" (p. 412), and is also commented on by Miller (1991), who states:

Written reports, books of accounts, pictures, charts (...) as technologies they do not have a neutral function of recording the real, but literally represent in such a way as to make it susceptible to evaluation, calculation and intervention (p. 318).

The visibility that the budget board provides is not, as Mouritsen (2004) stresses, "the end of the story but its beginning" (p. 266). This 'beginning' is invoked by dramatising the numbers (Catasús \& Gröjer, 2006), moving the family away from merely watching the numbers towards 'feeling' them.

In some Luxury Trap cases however, the money notes on the budget board are insufficient to make the advisors' point get through to the family. Many family members look at the board but do not see. Why is that so? Munro (1993) argues that the understanding of accounting devices as something that offers visibility is overrated and "carries with it overtones of a realist optics" (p. 251). Because even though they do promise visibility, it is not always obvious what exactly one is being enlightened about. What Munro implies is that visibility does not guarantee comprehension, stating that "sight only sees surfaces and finally it is understanding, not the visual that does the interpretive work" (p. 254). The activation of accounting numbers - even though materialised in notes - is in some cases not accomplished by the numbers themselves; they have to be brought to life through additional efforts. Hence, other signifying practices (Hall, 1997b) have to be mobilised for the moment of revelation to occur.

\subsubsection{The house inspection}

In several episodes, the advisors take the family members on an inspection of their own home. During this inspection, the family is confronted with explicit illustrations of their - in the advisors' view dysfunctional spending habits: rooms covered by piles of exclusive designer clothes, a garage packed with motorbikes, or a kitchen closet full of empty pizza boxes. Crary (1992) would call this kind of stocktake exercise a technique of the observer, as a way of "seeing oneself through the lens through which others see one" (Townley, 1996, p. 577). Walking through the house with the family, showing them how the advisors view their way of life, trains the family to see like the advisors. This constitutes a norm for the family to relate to, enabling them to identify blind spots of behaviour and attitudes that, according to the advisors, need to be worked upon, changed, or improved.

By stripping the participants' finances of their numerical representation, dressing them up in fashionable clothes, motorbikes and pizza boxes, the inspection exercise is said to provide the families with tangible evidence of what constitutes their irresponsible financial behaviour. By pinpointing the alleged origins of the numbers, which in Mouritsen's terms (2011) means fitting "an external reality to a [number] representation" (p. 232), the inspection is hoped to make the family understand what is 'hidden' behind the numbers.

\subsection{3. 'Emotional' bookkeeping}

On another occasion, the advisors introduce the family members to an exercise where they are instructed to employ a personal 'account book'. In one of the episodes (S6:E7), financial advisor 3 describes the task to the family as follows:

I brought you something. It's a diary. And I want you to use that in order to think before you make any purchases. I want you to stop, go home, and write down in the book whether this is something that you need. Like: 'do I really need this?' Write down the feeling standing there in the store. When we come back, I want you to have used it quite frequently.

This kind of 'emotional' bookkeeping is brought in as a preventive technique to enable the individual to identify the feelings that accompany the purchase occasion, and that are thought of as the core driving mechanism to his/her spending issues. By writing the emotions down, describing them, it is hoped that the account book will work as a kind of lifestyle evaluation, encouraging the family members to reflect on their own modes of living, on their choices of everyday life, and on their way of regulating bad behaviour. This kind of self-writing (Foucault, 1997) borrows from what Weber (1962) designates as "moral bookkeeping", a kind of "account-books in which sins, temptations, and progress made in grace were entered or tabulated" (p. 124). Such personal accounting is associated with the confessional and serves as a "safeguard against sinning" (Saint Athanasius in Foucault, 1997, p. 207) in the service of financially refined behaviour.

Even though the account book is employed in order to restrain a certain bad financial behaviour, it is not primarily used as a punishment for faulty past deeds taken. Instead, it serves as a conversation and reflection companion, with which one is to identify the inner impulses that drive the undesired behaviour (Aho, 2005). According to Thompson (1994), "writing creates a space for an internal, contemplative type of thought but above all else a visual form of thought" (p. 54). As such, the account book works as an inward-looking scrutiniser, used to shed light on the excessive impulses causing the numbers on the debt bills from which the individual suffers. The idea is that once identified and reflected upon, the individual is better equipped to recognise these impulses, and hence resist them.

Interestingly, accounting techniques such as the budget, the stock take and the bookkeeping are here brought in as technologies of visualisation, not only to make visible an underlying economic reality, as traditionally stressed in the accounting literature, but also a behavioural and 'emotional' reality. According to the programme's producers, the family's finances should be understood as a result of their everyday spending habits, and in that perspective accounting techniques are vital as pedagogical means to catch sight of that excessive behaviour. As such, they function as signifying practices (Hall, 1997d), mobilizing the family into becoming aware of and to acknowledge their finances differently.

In line with Hall, Vollmer (2007) advocates looking upon numbers as symptoms of reality. He argues that in order to establish the meaning of numerical accounts, one needs to interrogate their 'reality' origins, bringing their measures back from where they came from. It might therefor be concluded that even though numbers may produce effects on their environment, the budget board exercise, the tangible house inspection, as well as the personal account book stress that numbers at times need to be rendered in alternative ways, re-presented by other forms of accounts. Once it has been established what the numbers on bills, receipts and debt demands refer to in 'real life', the families are 
said to be sufficiently prepared to enter the next phase towards taking responsibility for the consequences of their past actions.

\subsection{From reality back into numbers}

The first phase of a Luxury Trap episode involves activities introducing the participants to their finances by means of numerical representations. In the second phase, the representations are stripped of their numerical form, anchoring them in 'reality' as tangible objects or personal feelings in order to make finances more comprehensible (Macintosh et al., 2000; Vollmer, 2007). However, next in the third and last phase of the episode, the qualitative 'reality' representations are transformed into quantitative accounts susceptible to comparison and measurability, to eventually regain their original form - numbers. Just as in previous phases, this transformation is accomplished by means of a selection of translation activities, here referred to as signifying practices (Hall, 1997d).

\subsubsection{The Lego calculus}

In one of the episodes (S8:E3), the viewers make the acquaintance of a woman, living alone with her teenage daughter in a small one-room cottage. The woman is portrayed as severely debt-ridden but yet unaware of the acuteness of her situation. In one scene of the programme, she is invited to a beautiful spacious house in which she is introduced to a Lego construction. Financial advisor 1 informs her:

When we look at your life it doesn't add up. We have to find out what it is that is of value in your life and how much that costs in money. So I made a compilation of your life.

He points out her beauty salon, her motorbike, her horse, her daughter and finally herself. Then he adds currency notes to each of the Lego items in order to demonstrate how much money she spends on the different parts of her life. The point, it is said, is to make her spending issues (behaviour) as visible as possible. Looking at the result, most of the money is spent on herself. To make the situation even worse, the advisor contrasts her spending habits to what she could have acquired instead: the new house in which the exercise takes place. Her reaction is in accordance with the advisor's expectations:

I'm bloody awful. That's easy to see. When I see how much I spend on myself, I feel egoistic, ashamed. But it's good to see the pattern because now I want to change.

Espeland and Stevens (2008) would call this exercise an act of commensuration. Commensuration refers to the "valuing or measuring of different objects with a common metric" (2008, p. 408), which "can change our relations to what we value and alter how we invest in things and people" (1998, p. 319). They argue that the turning of qualities into quantities creates new relations among things, potentially resulting in new ways of making assessments and evaluations. In this way, commensuration might help to transform the cognitive interpretive schemata of appreciating one's way of living. In the Lego calculus, all qualitative differences in the woman's life were translated into a common quantitative metric, manifested in currency notes. As such, it opened up an opportunity for her to compare and evaluate alternative ways of spending her money, making them amenable to rational comparison.

\subsubsection{The forced sale}

A compulsory element of the Luxury Trap's storyline is the sale of things the family cannot afford. This kind of liquidation of the family's belongings is not only a way of demonstrating a technique for dealing with debts and loans. It is also a way of addressing and reducing the sentimental value that the family members attach to their personal belongings. To change the relationship between the individual and the object, one has to intervene in the exchange between the object and the mental meaning that the individual ascribes to it in order to deconstruct and adjust it to another meaning. The effort it takes to break with the old relation to the object is dependent on how passionately the person feels about it, on its centrality in defining his/her identity (Espeland \& Stevens, 1998, p. 327). As numbers are claimed to foster detachment from feelings and passions, they abstract and distance the object from its owner, and enable the person to take a rational stance towards it. Or as Cohen (1999), drawing on Thomas Jefferson, puts it: "exclusive focus on the quantitative relegated feelings to the shadowy background" (p. 114).

The forced sale is as such an exercise in 'disattachment'. Even so, living it for the first time makes several participants experience feelings of relief and freedom. One of the participants describes the feeling as euphoric when overcoming her agony about selling off her jewelry and realising that these once so invaluable objects "are just stuff".

When I see these numbers, I just realise that we can solve a lot of things and that just feels so good. (S9:E6)

Just as was the case with the woman in the example of the Lego calculus, this commensuration enables her to compare the numbers that the forced sale has generated to other alternatives. As commensuration helps structure options in ways that make it obvious what to choose (Espeland \& Stevens, 1998), it opens up opportunities that had not been imaginable before the emotional relation to the objects was broken.

Through the abstraction and reduction of quality (the sentimental value of the object) to quantity (the price of the object), the forced sale is an exercise that makes formerly non-comparable objects comparable. Just as Rose argues, that numbers are "bound up with a certain way of approaching the world" (1991, p. 682), translating the emotional value into quantities is therefore claimed to change the participant's relation to the material object, and hence how s/he values it. Hence, when the representation changes, so does the interpretive experience of the object (Hall, 1997d). This paves the way for a new mode of thinking when establishing financial priorities, a mode that presupposes knowledge of how to relate numbers to other numbers (see Vollmer, 2007).

\subsubsection{The budget board revisited}

Once this basic foundation of interpreting numerical figures has been established, the family is hoped to be sufficiently equipped to take care of their own finances according to the budget revision that is made by the end of the Luxury Trap story. Here, the family encounters with a revised futuresque version of the budget board, outlining in detail the financial conditions to which the family needs to adjust in order to get back on track. The final part involves the family's core transformation. This is where the financial advisors leave the family on its own to find out whether it has been properly equipped to bear responsibility for its own finances, or not. This process is hidden from the viewers, intended to add excitement to the story. Once transformed into financially responsible (or not), the family enters the final scene. This is the time of acknowledgement, when the financial advisors return to the family to decide upon its success or failure. As the Luxury Trap story is one of triumphant transformation, happy endings are an obligatory constituent. As such, the makeovers always succeed.

To conclude, the analysis of the empirical data highlights the process of transformation that financial accounts are said to go through in order to become interpretable and acted upon by their recipients. Informed by Hall's communication theory $(1980,1997 a-d)$ the exercises performed throughout the episodes function as signifying practices concerned with a continuous and literal re-presentation of financial accounts. In the introductory phase of the Luxury Trap, the participants' finances are presented as numerical figures on receipts and debt demands. In the subsequent phase, the figures are stripped of their numerical garb and dressed up in other costumes corresponding to the 'reality' referents they are alleged to represent, such as physical objects and emotional states and impulses. Once the numbers are considered stabilised by being given 'real' content (Robson, 1992), the transformation of the financial accounts alters once more. In the third and 
concluding phase, the reality representations are replaced by quantifiable measures, enabling comparisons and priorities to be made between options. Like this, the Luxury Trap describes a round-trip translation journey between quantitative and numerical inscriptions on the one hand, and qualitative 'reality' referents on the other. The recurrent consecutive phases by which each episode is structured, endow the Luxury Trap with a pedagogical storyline emphasising that in order to better make sense to their intended recipients, financial accounts need to get dressed up in different representational guises. Hence, in order for the financial makeover to come out as successful, financial accounts are believed to require a makeover themselves.

\section{Concluding discussion}

The Luxury Trap tells us a story not only about the complexity of representing financial accounts, but also that the way of doing so convincingly is assumed to depend on who is identified as their intended audience. On the one hand, the story confirms what has long been acknowledged within the accounting realm: that numbers, calculations and technologies are powerful since they affect people's way of looking upon and acting in the world. On the other hand, it addresses one of accounting's perhaps less examined assumptions: that in order to become powerful, to matter and to be believed to make a difference to people, financial information needs to be interpretable to its users. This paper is an attempt to investigate this assumption more specifically.

Contrary to the claim that numbers add credibility to stories (Mouritsen, Larsen, \& Bukh, 2001; Porter, 1995), the empirical findings of this paper reveal that in vistas where the audience is either unaccustomed to or, uninterested or, for whatever reason, impaired in making sense of numbers, communicating financial accounts in numerical forms is assumed to be of no relevance. In fact, in such cases numbers are claimed to add nothing. In this way, the paper's findings contribute to problematise the constitutive power of accounting by implying that a direct impact of accounts cannot be taken for granted. Rather, the paper anchor and refine the observation made by, for example, Ezzamel et al. (2004) that the effects of accounts are dependent on how they are made meaningful to their recipients. They demonstrate that in cases where recipients' interpretations of financial information are ambiguous and vary (Abrahamsson et al., 2016), translations that imbue accounts with at specific meaning are assumed to be required. In the Luxury Trap, such translations were achieved by coming up with, what Hall (1997d) calls, signifying practices, i.e. exercises that provide the information with meaning applicable to its participants. In the following, the paper discusses conclusions drawn from the paper's findings of those meaning-making practices.

According to Hall (1997b), constructing meaning involves translating information so as to fit the interpretation scheme of its recipient. This means that to come across as conceivable to people, as something to be reckoned with and acted upon, financial numbers, concepts and accounts ought to be inscribed with lots of context (Vollmer, 2007), integrating them into the recipient's own everyday practices and conditions, interests and needs. In the Luxury Trap, this is accomplished by re-constructing the appearances of numerical accounts into taking the form of physical objects or emotional states found in the daily life of the participants. Hence, the accomplishment of giving meaning to financial accounts is dependent on the producer's pedagogical skills to re-present (Hall, 1997a) or, as put elsewhere in the accounting literature, contextualise (Ahrens \& Chapman, 2007), customise (Quattrone \& Hopper, 2006), translate (Briers \& Chua, 2001), or negotiate (Qu \& Cooper, 2011) accounts so as to be recognisable to their intended audience. Contextualisation might in this sense be understood as an attempt to trace the numbers' origins by framing the numericals in relation to what Vollmer (2007) refers to as a "working version of reality" (p. 587), making visible the sources to which the numbers is said to refer.

This, in turn, suggests that the ability of financial accounts to influence its environment rests on the myth of correspondence (cf.
Solomons, 1978, 1991). Adherents of accounting's constitutive turn often take a sceptical view of the alleged correspondence of numbers with 'reality', and occasionally even refer to numbers as made-ups, constructs, cheaters and bullshitters (Chua, 1995; Hines, 1988; Hirst, 1981; Macintosh et al., 2000; Mouritsen, 2011). Nevertheless, and regardless of their truthfulness to reality, numbers may still exert influence on its environment. It is through convincing people to believe that the number - bullshitted or not - actually does have a real origin that it acquires its power to make an impact. In the Luxury Trap, this is done by framing the number in relation to the context it refers to, depicted in ways so that the number's link to reality comes across as trustworthy, credible and realistic to its recipient. Hence, the constitutive strength of accounting to influence its audience in a certain direction is assumed to boil down to a matter of conviction, conditioned by making people see, i.e. believe (Chua, 1995), that a correspondence between the accounting sign and its 'reality' referent exists.

In addition, and perhaps most interestingly, being made aware of the numbers' 'reality' origins is not only claimed to make the participants see but also to feel what the numbers stand for. This is said to be of critical significance. In the Luxury Trap, arranging the meaning-making exercises of financial information so as to provoke the participants to be emotionally affected serves as a wake-up call, forcing the participants to interpret and relate to their finances differently. This resonates with Faÿ, Introna, and Puyou (2010), claiming that "numbers and other representations are not only perceived cognitively but also affectively" (p. 27). Still, apart from a few exceptions, (e.g. Pentland, 1993; Carrington \& Catasús, 2007; Boedker \& Chua, 2013; Guenin-Paracini, Malsh, \& Marché Paille, 2014), research offering insights into the role that feelings, emotions and sentiments play in relation to accounting is only in its infancy. This indicates that we still know little about how emotions drive or hinder, enable or circumscribe the way that people read financial accounts. Hence, the affect effect of accounting is left noticeably unaddressed and calls for further investigation.

Moreover, the numerous translation phases that financial accounts pass through indicate that accounting might be perceived as a result of an on-going process, rather than as something absolute. This suggests that accounting boundaries are continuously re-negotiated, emphasized by Miller (1998) stating that "there are no general principles by which one might be able to arbitrate as to what should be inside and what outside accounting (p. 619). Rather, by using whatever design is at hand, the financial advisors in the Luxury Trap stretch or even erase any border in the search for what might be considered suitable for re-presenting financial accounts. And most importantly, they continue to do so until a 'satisfactory' interpretation of their meaning has been established. Hence, what constitutes accounting and its representations becomes an empirical question, ultimately motivated and determined by what is believed to make it interpretable.

Apart from its attempt to theoretically contribute to the accounting literature, the paper also widens the empirical scope of accounting investigation. In spite of a growing understanding of accounting as something that has come to permeate everyday life (Hopwood, 1994), previous research has, as Napier (2006) puts it, "a tendency to view the actions and practices of élites as inherently more important than the life of 'ordinary people"' (p. 459). By consequence, most research concerning the impact of accounting has been conducted on the organisational level, studying how accounting representations, technologies, and vocabulary influence and change people's professional working conditions (Jeacle, 2009, 2012). By contrast, to study how accounting is casted in a televised financial makeover show, attempting to influence people's attitude towards their own private financial affairs, serves as a response to a growing call in the social accounting community: to further explorations of the interpenetration between accounting and society in the everyday life of 'ordinary' people (see e.g. Hopwood, 1994; Miller, 2007; Mennicken, Miller, \& Samiolo, 2008; Jeacle, 2009, 2012). Hence, unlike the bulk of accounting research preoccupied with the professional activities within organisations, this paper targets the 
sphere of people's domestic financial management, a field of investigation that has long been disregarded and only marginally examined (for exceptions, see e.g. Llewellyn \& Walker, 2000; Walker \& Llewellyn, 2000; Carnegie \& Walker, 2007a, b; Vargha, 2011).

Following from this argument, another possible topic of further research emerges. Even though the paper's conclusions originate from findings drawn from studying the private sphere of people's everyday financial life, the question might nevertheless be raised whether they bear any relevance to studies of the organisational sphere. Since rarely touched upon in previous literature, it might be justified to ask whether the ability of organisational members to decode accounting information is taken for granted, or if actors at any level or arena of society business journalists, board room members, CEOs, controllers, stockbrokers and even accounting academics - face difficulties in interpreting and explaining accounting not only to others but also to themselves. As such, the issue of making sense of accounting might possibly be revealed as a topic of investigation that is as valid in the professional world as it is in the non-professional one.

\section{Acknowledgements}

The writing of this paper was enabled by funding from Handelsbanken, Sweden. The author would like to acknowledge the helpful comments of David J. Cooper, Yves Gendron, Bino Catasús, Gustav Johed, the MUSICA research group at Stockholm Business School, and the two anonymous AOS reviewers.

\section{References}

Abrahamsson, G., Englund, H., \& Gerdin, J. (2016). On the (re)construction of numbers and operational reality. Qualitative Research in Accounting \& Management, 13, $159-188$.

Aho, J. (2005). Confession and Bookkeeping: The religious, moral, and rhetorical roots of modern accounting. Albany: State University of New York Press.

Ahrens, T. (1996). Styles of accountability. Accounting, Organizations and Society, 21(2/3), 139-173.

Ahrens, T. (1997). Talking Accounting: An ethnography of management knowledge in british and German brewers. Accounting, Organizations and Society, 22(7), 617-637.

Ahrens, T., \& Chapman, C. S. (2007). Management accounting as practice. Accounting, Organizations and Society, 32(1-2), 1-27.

Almenberg, J., \& Widmark, O. (2011). Räknefärdighet och finansiell förmåga: Preliminära resultat från Finansinspektionens konsumentundersökning 2010. Stockholm: Finansinspektionen.

Andrews, M., \& Carter, F. (2008). 'Who let the dogs Out?': pets, parenting and the ethics of lifestyle programming. In G. Palmer (Ed.). Exposing lifestyle television: The big reveal. Hampshire: Ashgate.

Arrington, E. C., \& Francis, J. R. (1993). Giving economic accounts: Accounting as cultural practice. Accounting, Organizations and Society, 18(2-3), 107-124.

Asdal, K. (2011). The office: The weakness of numbers and the production of non-authority. Accounting, Organizations and Society, 36(1), 1-9.

Bauman, Z. (1987). Legislators and interpreters. Oxford: Blackwell.

Bay, C., Catasús, B., \& Johed, G. (2014). Situating financial literacy. Critical Perspectives on Accounting, 25, 36-45.

Boedker, C., \& Chua, W.-F. (2013). A study of circulation, agency and entrancement. Accounting, Organizations and Society, 38, 245-267.

Boland, R. J. (1993). Accounting and the interpretive act. Accounting, Organizations and Society, 18, 125-146.

Bonner, F. (2003). Ordinary Television: Analyzing popular TV. London: Sage Publications.

Briers, M., \& Chua, W.-F. (2001). The role of actor-networks and boundary objects in management accounting change: A field study of an implementation of activity-based costing. Accounting, Organizations and Society, 26(3), 237-269.

Brown, A. D., Yiannis, G., \& Gherardi, S. (2009). Storytelling and Change: An unfolding story. Organization, 16(3), 323-333.

Brunsdon, C. (2004). Taste and time on television. Screen, 45(2), 115-129.

Carnegie, G. D., \& Walker, S. P. (2007a). Household accounting in Australia: Prescription and practice from the 1820 s to the 1960s. Accounting, Auditing \& Accountability Journal, 20(2), 210-236.

Carnegie, G. D., \& Walker, S. P. (2007b). Household accounting in Australia: A microhistorical study. Accounting, Auditing \& Accountability Journal, 20(1), 41-73.

Carrington, T., \& Catasús, B. (2007). Auditing stories about discomfort: Becoming comfortable with comfort theory. European Accounting Review, 16, 35-58.

Carruthers, B. G., \& Espeland, W. N. (1991). Accounting for rationality: Double-entry bookkeeping and the rhetoric of economic rationality. American Journal of Sociology, 97(1), 31-69.

Catasús, B. (2010). Indicators as technology: Debates on the link between indicators and action (unpublished paper). Presented at the european accounting association conference (EAA) in Istanbul, may 2010.
Catasús, B., Ersson, S., Gröjer, J.-E., \& Wallentin, F. Y. (2007). What gets measured gets... on indicating, mobilizing and acting. Accounting, Auditing \& Accountability Journal, 20(4), 505-521.

Catasús, B., \& Gröjer, J.-E. (2006). Indicators: On visualizing, classifying and dramatizing. Journal of Intellectual Capital, 7(2), 187-203.

Chaney, D. (2001). From ways of life to Lifestyle: Rethinking culture as ideology and sensibility. In J. Lull (Ed.). Culture in the communication age (pp. 75-88). London: Routledge.

Chua, W. F. (1995). Experts, networks and inscriptions in the fabrication of accounting images: A story of the representation of three public hospitals. Accounting, Organizations and Society, 20(2-3), 111-145.

Cohen, P. C. (1999). A Calculating People: The spread of numeracy in early America. New York: Routledge.

Crary, J. (1992). Techniques of the observer: On vision and modernity in the 19th century. Cambridge, MA: MIT Press.

Czarniawska, B. (1997). Narrating the Organization: Dramas of institutional identity. Chicago: University of Chicago Press.

Czarniawska, B. (2000). The uses of narrative in organization researchGRI Report 2000:5. Gothenburg: Gothenburg Research Institute.

Czarniawska, B. (2004). Narratives in social science research. London: Sage Publications.

Erturk, I., Froud, J., Johal, S., Leaver, A., \& Williams, K. (2007). The democratization of finance? Promises, outcomes and conditions. Review of International Political Economy, 14(4), 553-575.

Espeland, W. N., \& Stevens, M. L. (1998). Commensuration as a social process. Annual Review of Sociology, 24, 313-343.

Espeland, W. N., \& Stevens, M. L. (2008). A sociology of quantification. European Journal of Sociology, 49(03), 401-436.

Ezzamel, M., Lilley, S., \& Willmott, H. (2004). Accounting representation and the road to commercial salvation. Accounting, Organizations and Society, 29(8), 783-813.

Faÿ, E., Introna, L., \& Puyou, F.-R. (2010). Living with numbers: Accounting for subjectivity in/with management accounting systems. Information and Organization, 20, 21-43.

Finlayson, A. (2009). Financialisation, financial literacy and asset-based welfare. The British Journal of Politics \& International Relations, 11(3), 400-421.

Fisher, W. R. (1984). Narration as a human communication paradigm: The case of public moral argument. Communication Monographs, 51(1), 1.

Foucault, M. (1997). Self writing. In P. Rabinow (Ed.). Michel Foucault: Ethics, subjectivity and truth. New York: The New Press.

Frank, T. (2001). One market under God: Extreme capitalism, market populism, and the end of economic democracy. London: Secker \& Warburg.

FridayTV (2009). Luxury Trap. Information sheet. Metronome Group).

Grafström, M. (2005). Nyheter på ekonomiska. In B. Rombach (Ed.). Den framgångsrika ekonomiskan. Stockholm: Santérus förlag.

Greenfield, C., \& Williams, P. (2007). Financialization, finance rationality and the role of media in Australia. Media, Culture \& Society, 29(3), 415-433.

Greimas, A. J., \& Courtés, J. (1979/1982). Semiotics and Language: An analytical dictionary. In T. A. Sebeok (Ed.). Advances in semiotics. Bloomington: Indiana University Press.

Guenin-Paracini, H., Malsh, B., \& Marché Paille, A. (2014). Fear and risk in the audit process. Accounting, Organizations and Society, 39, 264-288.

Hall, S. (1980). Encoding/decoding. In S. Hall, D. Hobson, A. Lowe, \& P. Willis (Eds.). Culture, media, Language: Working papers in cultural studies 1972-79. London: Routledge.

Hall, S. (Ed.). (1997). Representation: Cultural representations and signifying practices. London: Sage Publications.

Hall, S. (1997b). Introduction. In S. Hall (Ed.). Representation: Cultural representations and signifying practices (pp. 1-11). London: Sage Publications.

Hall, S. (1997c). The work of representation. In S. Hall (Ed.). Representation: Cultural representations and signifying practices (pp. 13-74). London: Sage Publications.

Hall, S. (1997d). Representation and the media. In S. Talreja, S. Jhally, \& M. Patierno (Eds.). Media education foundation transcriptNorthhampton: Media Eduction Foundation Featuring a lecture by Stuart Hall at the University of Westminster London.

Harmes, A. (2001). Mass investment culture. New Left Review, 9(May/June), 103-124.

Hines, R. D. (1988). Financial accounting: In communicating reality, we construct reality. Accounting, Organizations and Society, 13(3), 251-261.

Hirst, M. K. (1981). Accounting information and the evaluation of subordinate performance: A situational approach. The Accounting Review: American Accounting Association, 56(4 Oct), 771-784.

Hopwood, A. G. (1987). The archaeology of accounting systems. Accounting, Organizations and Society, 12(3), 207-234.

Hopwood, A. G. (1994). Accounting and everyday Life: An introduction. Accounting, Organizations and Society, 19(3), 299-301.

Jeacle, I. (2009). Accounting and everyday life: Towards a cultural context for accounting research. Qualitative Research in Accounting and Management, 6(3), 120-136.

Jeacle, I. (2010). Accounting and popular culture. Call for papers: Special issue. Accounting, Auditing \& Accountability Journal, 23(3).

Jeacle, I. (2012). Accounting and popular Culture: Framing a research agenda. Accounting, Auditing \& Accountability Journal, 25, 580-601.

Johed, G. (2007). Accounting, stock markets and everyday lifeDoctoral Thesis. Uppsala: Department of Business Studies, Uppsala University.

Kirk, K., \& Mouritsen, J. (1996). Spaces of Accountability: Explaining the imposition of managing by accounting. In R. Munro, \& J. Mouritsen (Eds.). Accountability: Power, ethos \& the technologies of managing (pp. 245-260). London: International Thomson Business Press.

Langley, P. (2007). Uncertain subjects of Anglo-American financialization. Cultural 
Critique, 65(Fall), 67-91.

Langley, P. (2008). The everyday life of global Finance: Saving and borrowing in AngloAmerica. Oxford: Oxford University Press.

Lewis, T. (2008). Smart Living: Lifestyle media and popular expertise. New York: Peter Lang Publishing.

Llewellyn, S., \& Walker, S. P. (2000). Household accounting as an interface Activity: The home, the economy and gender. Critical Perspectives on Accounting, 11(4), 447-478.

Macintosh, N. B., Shearer, T., Thornton, D. B., \& Welker, M. (2000). Accounting as simulacrum and hyperreality: Perspectives on income and capital. Accounting, Organizations and Society, 25(1), 13-50.

Martin, R. (2002). The financialization of daily life. Philadelphia: Temple University Press. Mennicken, A., Miller, P., \& Samiolo, R. (2008). Accounting for economic sociology. Economic Sociology, The European Electronic Newsletter, 10(1) November).

Messner, M. (2009). The limits of accountability. Accounting, Organizations and Society, 34(8), 918-938.

MeterFilm Production (2009). The Luxury Trap. Demo Tape).

Miller, P. (1991). Accounting innovation beyond the enterprise: Problematizing investment decisions and programming economic growth in the UK in the 1960s. Accounting, Organizations and Society, 16(8), 733-762.

Miller, P. (1994). Accounting as a social and institutional practice: An introduction. In A. G. Hopwood, \& P. Miller (Eds.). Accounting as a social and institutional practice. Cambridge: Cambridge University Press.

Miller, P. (1998). The margins of accounting. European Accounting Review, 7(4), 605-621.

Miller, P. (2001). Governing by Numbers: Why calculative practices matter. Social research (pp. 379-396). New School for Social Research.

Miller, P. (2007). Management accounting and sociology. In C. S. Chapman, A. G. Hopwood, \& M. D. Shields (Eds.). Handbook of management accounting research. Elsevier Ltd.

Miller, P., \& O'Leary, T. (1990). Making accountancy practical. Accounting, Organizations and Society, 15(5), 479-498.

Mouritsen, J. (2004). Measuring and Intervening: How do we theorize intellectual capital management? Journal of Intellectual Capital, 5(2), 257-267.

Mouritsen, J. (2011). The operation of representation in accounting: A small addition to dr. Macintosh's theory of accounting truths. Critical Perspectives on Accounting, 22(2), 228-235.

Mouritsen, J., Larsen, H. T., \& Bukh, P. N. D. (2001). Intellectual capital and the 'capable firm': Narrating, visualising and numbering for managing knowledge. Accounting, Organizations and Society, 26(7-8), 735-762.

Munro, R. (1993). Just when you thought it safe to enter the water: Accountability, language games and multiple control technologies. Accounting, Management and Information Technologies, 3(4), 249-271.

Napier, C. (2006). Accounts of change: 30 years of historical accounting research. Accounting, Organizations and Society, 31(4-5), 445-507.

Oakes, L. S., Townley, B., \& Cooper, D. J. (1998). Business planning as Pedagogy: Language and control in a changing institutional field. Administrative Science Quarterly, 43(2), 257-292.

OECD (2005). Improving financial Literacy: Analysis of issues and policies. OECD Press.

Ouellette, L., \& Hay, J. (2008). Better living through reality TV: Television and post-welfare citizenship. Malden, MA: Blackwell Publishing.

Pentland, B. T. (1993). Getting comfortable with numbers: Auditing and the micro-production of macro order. Accounting, Organizations and Society, 18, 605-620.

Porter, T. (1995). Trust in Numbers: The pursuit of objectivity in science and public life. Princeton NJ: Princeton University Press.

Quattrone, P. (2009). Books to be practiced: Memory, the power of the visual, and the success of accounting. Accounting, Organizations and Society, 34(1), 85-118.

Quattrone, P., \& Hopper, T. (2006). What is IT? SAP, accounting, and visibility in a multinational organisation. Information and Organization, 16, 212-250.

Qu, S. Q., \& Cooper, D. J. (2011). The role of inscriptions in producing a balanced scorecard. Accounting, Organizations and Society, 36(6), 344-362.

Redden, G. (2007). Makeover morality and consumer culture. In D. Heller (Ed.). Makeover Television: Realities remodelled (pp. 150-164). London: I.B. Tauris.

Rehn, A., \& Sköld, D. (2010). From wallet arithmetics to stock-market thriller. In B. Rombach, \& P. Zapata (Eds.). The rise of management-speak. Stockholm: Santérus Academic Press.

Roberts, J. (1991). The possibilities of accountability. Accounting, Organizations and Society, 16(4), 355-368.

Roberts, J., \& Scapens, R. (1985). Accounting systems and systems of accountability: Understanding accounting practices in their organisational contexts. Accounting, Organizations and Society, 10, 443-456.

Robichaud, D. (2003). Narrative institutions we organize By: The case of municipal administration. In B. Czarniawska, \& P. Gagliardi (Eds.). Narratives we organize by. Amsterdam/Philadelphia: John Benjamins Publishing Company.

Robson, K. (1992). Accounting numbers as "inscription": Action at a distance and the development of accounting. Accounting, Organizations and Society, 17(7), 685-708.

Rose, N. (1991). Governing by numbers: Figuring out democracy. Accounting, Organizations and Society, 16(7), 673-692.

Shannon, C. E. (1948). A mathematical theory of communication. The Bell System Technical Journal, 27(July; October) 379-432; 623-656.

Sinclair, A. (1995). The chameleon of accountability: Forms and discourses. Accounting, Organizations and Society, 20(2-3), 219-237.

Singhal, A., \& Rogers, E. M. (1999). Entertainment-education: A communication strategy for social change. Mahwah, New Jersey: Lawrence Erlbaum Associates Publishers.

Solomons, D. (1978). The politicization of accounting: The impact of politics on accounting standards. Journal of Accountancy, 146(5), 65-72.

Solomons, D. (1991). Accounting and social change: A neutralist view. Accounting Organizations and Society, 16(3), 287-295.

Taylor, L. (2002). From ways of life to Lifestyle: The 'Ordinari-ization' of british gardening lifestyle television. European Journal of Communication, 17(4), 479-493.

Thompson, G. (1994). Early double-entry bookkeeping and the rhetoric of accounting calculation. In A. Hopwood, \& P. Miller (Eds.). Accounting as a social and institutional practice. Cambridge: Cambridge University Press.

Townley, B. (1996). Accounting in detail: Accounting for individual performance. Critical Perspectives on Accounting, 7(5), 565-584.

Vargha, Z. (2011). From long-term savings to instant mortgages: Financial demonstration and the role of interaction in markets. Organization, 18(2), 215-235.

Vollmer, H. (2003). Bookkeeping, accounting, calculative practice: The sociological suspense of calculation. Critical Perspectives on Accounting, 3, 353-381.

Vollmer, H. (2007). How to do more with numbers: Elementary stakes, framing, keying, and the three-dimensional character of numerical signs. Accounting, Organizations and Society, 32(6), 577-600.

Walker, S. P., \& Llewellyn, S. (2000). Accounting at home: Some interdisciplinary perspectives. Accounting, Auditing \& Accountability Journal, 13(4), 425-449.

Weber, M. (1962). The protestant ethic and the spirit of capitalism. London: George Allen \& Unwin Ltd.

Williams, T. (2007). Empowerment of whom and for What? Financial literacy education and the new regulation of consumer financial services. Law \& Policy, 29(2), 226-256.

Young, J. (2003). Constructing, persuading and silencing: The rhetoric of accounting standards. Accounting, Organizations and Society, 28(6), 621-638. 